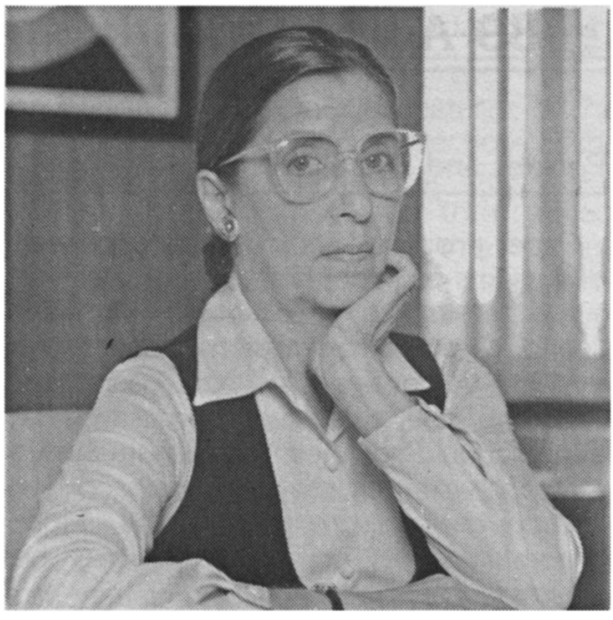

RUTH BADER GINSBURG

Photo by Paula Darte

attractive career choice for motivated and talented young people.

The Roundtable, convened by Charles $H$. Levine, American University, will also include Nancy Neuman, President of the League of Women Voters, and Norman J. Ornstein, The American Enterprise Institute.

\section{Judge Ginsburg \\ Will Talk on \\ Women and the Constitution}

Judge Ruth Bader Ginsburg of the U.S. Court of Appeals, D.C. Circuit, will present a talk on "Women Becoming Part of the Constitution" on Thursday, September l, at 5:30 p.m. The talk is presented as part of the meetings of the APSA and is co-sponsored by the Women's Caucus for Political Science and the Organized Section on Women and Politics Research.

Judge Ginsburg was appointed to the Circuit Court in 1980, and previously was a professor at Columbia University School of Law and Rutgers University School of Law. She spent a year at the Center for Advanced Study in Behavioral Sciences at
Stanford University as a Fellow, and has worked as General Counsel to the American Civil Liberties Union. She has served on the Advisory Board for Project ' 87 , of the American Historical and Political Science Associations. Time Magazine named her one of ten outstanding law professors in 1977, and in 1979 she was named winner of the Annual Outstanding Teacher of Law Award by the Society of American Law Teachers.

\section{APSA Research Grantees Announced for 1988}

The APSA Research Support Committee announced the 1988 Research Grantees on May 1. The Council established the Research Grant program in 1984, and authorized $\$ 15,000$ to be distributed annually. To be eligible for a grant, the applicants must be APSA members and must either be a faculty member at a non-Ph.D. granting college or university or be a political scientist not affiliated with an academic institution. Funds are used for research that addresses a significant problem in political science.

The Selection Committee, composed of Paul Hammond, University of Pittsburgh, chair; Huey Perry, Southern University; Christine Sierra, University of New Mexico; Howard Wiarda, University of Massachusetts; and Richard F. Winter, Dartmouth College, reviewed 33 applications and awarded 10 grants for 1988. The grantees are:

Denise Boer, Northeastern University. "Circulation of Elites in a Nationalized Party System-Federal Campaign Consultants and Congressional Committee Campaign Staff." \$1,500.

Janet K. Boles, Marquette University. "The Impact of Women's Policy Networks on the Redesign of Urban Services." $\$ 1,500$.

William E. Dugan, New Mexico State University. "Interest Representation in the Chilean Agricultural and Commercial Sectors." \$1,500. 